\title{
HPLC analysis of Polycyclic Aromatic Hydrocarbons(PAHs) in Mussels(Mytilus edulis) living in the Intertidal Zone of Kori, Korea
}

\author{
II Noh \\ Department of Environmental Engineering, Korea Maritime University \\ (Manuscript received 1 February, 2002 ; accepted 25 May, 2002)
}

\begin{abstract}
Polycyclic aromatic hydrocarbons(PAHs) are ubiquitous contaminants in coastal marine environment. PAHs enter estuarine and nearshore marine environment via several routes such as combustion of fossil fuels, domestic and industrial effluents and oil spills.

In August of 1997, mussels(Mytilus edulis) were collected at 6 sites near Kori nuclear power plant in order to analyze the PAH content by HPLC with uv/vis detection. Unfortunately, I could not find any living oysters in which I firstly intended to measure the PAH content in the study area.

NPTHL and ANCPL were the major dominant PAH compounds in mussels living in the intertidal zone of Kori, Korea, and DahA, BbF, BaP were the next dominant PAH group in mussels in the study area.

The mean concentrations of $15 \mathrm{PAH}$ in mussels ranged from 3.2 to $1,680 \mathrm{ppb}$ (mean $105 \pm 60.5$ $\mathrm{ppb})$.

Compared with other studies world over, the concentrations of carcinogenic PAHs were relatively low in mussels in the study area, even though total PAH content was rather high. According to $\mathrm{N} / \mathrm{P}(\mathrm{Naph}$ thalene/Phenanthrene) ratio(147) and the ratio of $2 \sim 3$ ring to $3 \sim 5$ ring PAHs $(58 \sim 90 \%)$ in mussels in the study area, I expect that the major source of PAHs in this study area is rather fresh petroleum-derived.

This study presents preliminary data for the PAH levels in mussels from the intertidal zone of Kori, and the data will hopefully be utilized for the assessment of oil pollution in the East Sea, Korea.
\end{abstract}

Key words :

\section{Introduction}

Estuarine and coastal environments are affected by various kinds of pollutants. Of all things, oil pollution has recently received the greatest public attention because of the direct damage to fisheries, and the harmful effects on marine lives.

Polycyclic or polynuclear aromatic hydrocarbons(PAHs) are a group of compounds composed of two or more fused aromatic rings. PAHs have

Corresponding author ; Il Noh, Department of Environmental Engineering, Korea Maritime University Phone : +82-51-410-4327

E-mail : ilnoh@hanara.kmaritime.ac.kr been the focus of numerous studies in the world because they are potentially carcinogenic, mutagenic, and teratogenic to aquatic organisms and humans consuming PAH- contaminated food.

PAHs enter marine environment via several routes ; domestic and industrial effluents, oil spill, incomplete combustion of fossil fuels, forest and brush fires, terrestrial contributions and natural sources such as biosynthesis by plant and microorganisms. However, oil spill and incomplete combustion of fossil fuels are major sources of PAHs in marine environment ${ }^{10,11)}$. They typically adsorb to fine particulate materials suspended in estuarine waters and sediment seafloor ${ }^{4)}$. 
Once PAHs have been introduced to a harbor or coastal zone, they accumulate in sediments because of their hydrophobicity and partitioning to the organic carbon-coated particles ${ }^{6}$. Since PAHs have low solubility in water and tend to be transported with suspended sediment, most PAHs introduced into aquatic environments are accumulated in bottom sediment. PAHs, as well as other organic pollutants, remain in the sediment usually depending on their rate of degradation in sediments ${ }^{3}$. Mussels and oysters are intertidal and subtidal organisms, which attach themselves to various substances and filter-feed on suspension. This study tried to analyze PAH concentration in intertidal organisms(especially mussels and oysters) in the East Sea of Korea filter-feeding on suspended particles on which PAH compounds, if present, were adsorbed.

Measurement of PAHs in living organisms in the intertidal zone of East Sea can hardly be found up to the present. This study tried to develop the method of PAH measurement in intertidal organisms living in the East Sea of Korea by High Performance Liquid Chromatography(HPLC), which has been used world-wide in measurement of PAHs in marine organisms.

This study presents preliminary data on the PAH levels in mussels(and oysters, in which I firstly intended to measure PAH content, however, failed to sample) from the intertidal zone near Kori nuclear power plant in order to contribute to the establishment of database on PAH contamination in mussels in the East Sea of Korea. And this study also tried to trace the possible sources of PAHs accumulated in mussels living in the vicinity of Kori nuclear power plant.

\section{Materials And Methods}

\subsection{Chemicals}

15 unsubstituted PAHs in coastal environment near Kori nuclear power plant were investigated: Naphthalene(NPTHL), Acenaphthylene(ANCPL), Acenaphthene(ACNPN), Fluorene(FLURN), Phenanthrene(PHEN), Anthracene(ANTHR), Fluoranthene(FLRTH), Pyrene(PYR), Chrysene(CHRY), Benzo(b)fluoranthene(BbF), Benzo(k)fluoranthene(BkF), Benzo(a)pyrene (BaP), Dibenz(a,h) anthracene (DahA), Benzo(g.h.i)peryline (BghiP) and Indeno(1,2,3,-cd)pyrene (I123cdP). Of those, EPA recently reported that the following seven PAHs are typically considered as possible or probable carcinogens : Chrysene (CHRY), Benzo(b) fluoranthene $(\mathrm{BbF})$, Benzo(k)fluoranthene (BkF), Benzo(a)pyrene (BaP), Dibenz(a,h)anthracene (DahA), Benzo(g.h.i)peryline (BghiP) and Indeno $\left(1,2,3\right.$, -cd)pyrene (I123cdP) ${ }^{7}$.

\subsection{Sampling and Extraction of PAHs from mussels(Mytilus edulis)}

Mussels(Mytilus edulis) were collected at six sites by SCUBA divers from $1.5 \sim 3 \mathrm{~m}$. water depth near the intertidal zone of Kori nuclear power plant, Korea, during August of 1997(Fig. 1).

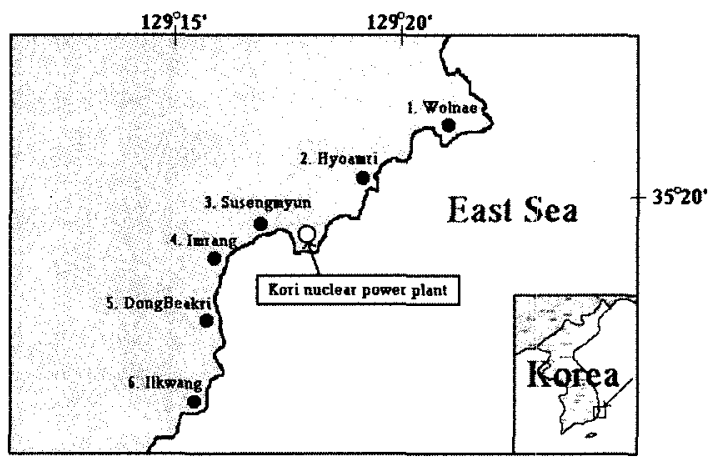

Fig. 1. Location of sampling sites in the East Sea, Korea.

Sampling sites were located in near residential area. Domestic wastewater and runoff have been discharged into this area via several streams., red tides tend to occur annually in this area In summer seasons.

The length of the mussels ranged from $3 \pm 0.11$ $\mathrm{cm}$ to $3.8 \pm 0.08 \mathrm{~cm}$, indicating they were young specimens. Samples were stored frozen under darkness in an icebox to minimize possible degradation caused by photo-oxidation or bacterial action and brought to the lab, and stored at $-20{ }^{\circ} \mathrm{C}$ prior to analysis. Glass devices were prepared by heating at $450{ }^{\circ} \mathrm{C}$ to remove any possible organic contamination.

HPLC grade reagents(hexane, acetone, diethylether, petroleum ether, methanol, dimethylsulfoxide(DMSO), cyclohexane, etc.) and ultrapure distilled water were used for all extraction procedures. The shells were removed and the tissue 
of mussels $(20 \mathrm{~g}$, wet $w \mathrm{t})$ were homogenized with macerator and dried with anhydrous sodium sulfate $\left(\mathrm{Na}_{2} \mathrm{SO}_{4}\right)$. The fats in thimble filter were Soxhletextracted with a mixture of hexane, acetone, diethylether and petroleum ether for 6 hour $^{11)}$. Then the fatty residues mixed with methanol containing $7 \mathrm{~g}$ of potassium hydroxide $(\mathrm{KOH})$ were refluxed for 3 hours. After digestion, the solution was separated three times with a cyclohexane ${ }^{12,13)}$. To separate PAHs from the aliphatic hydrocarbons, the liquid-liquid extraction procedure applied with dimethylsulfoxide(DMSO) ${ }^{9}$. The remaining portion was partitioned three times with a cyclohexane and evaporated to $1 \mathrm{ml}$ volume under a stream of nitrogen gas. Concentration of PAHs in mussel are expressed in units of $\mu \mathrm{g} / \mathrm{kg}$ wet weight.

\subsection{HPLC system}

The analysis of PAHs in mussels was carried out by computer-assisted HPLC system(Linear Instrument Co.), equipped with a Model S-1100 binary solvent delivery system, a Model S-2000 automatic gradient controller and an injector fitted with a GROM-SIL 120 ODS-5 ST column $(250 \times 4$ $\mathrm{mm}, 5 \mu \mathrm{m}$ particle size).

The flow rate of mobile phase was held constant at $0.8 \mathrm{~m} \ell / \mathrm{min}$ under the condition of $0.5 \mathrm{bar}$ pressure.

Solvent A of acetonitril and solvent B composed of ultrapure distilled water and acetonitril $(50: 50$, $\mathrm{v} / \mathrm{v}$ ) were utilized as mobile phases.

A gradient solvent system for the elution of PAHs in this study was programmed as follows : delivery program of solvent was planned at $100 \%$ solvent $\mathrm{B}$ for the initial condition, $70 \%$ solvent $\mathrm{B}$ at 5 min, $20 \%$ solvent $\mathrm{B}$ at $15 \mathrm{~min}, 10 \%$ solvent $\mathrm{B}$ at $20 \mathrm{~min}, 5 \%$ solvent $\mathrm{B}$ at $25 \mathrm{~min}$, and then followed by isocratic held $100 \%$ solvent A until $30 \mathrm{~min}$ (Table 1).

Sample was injected by using $20 \mu \ell$ syringe. Analytical blank test was carried out between each sample run and no analytical contamination has found in the HPLC system.

The peaks of PAHs were identified and quantified using uv/vis detection setting at $254 \mathrm{~nm}$. The management of chromatograms, integration and calibration of data were carried out using Peaksimple Serial Data Program system(SRI Model 202).
Table 1 . Binary gradient program used in this study

\begin{tabular}{r|c|c}
\hline \multirow{2}{*}{$\begin{array}{c}\text { Time } \\
(\min )\end{array}$} & Solvent $\mathrm{A}$ & \multicolumn{1}{|c}{ Solvent $\mathrm{B}$} \\
\cline { 2 - 3 } & $\mathrm{CH}_{3} \mathrm{CN}(\%)$ & $\begin{array}{l}\mathrm{H}_{2} \mathrm{O}: \mathrm{CH}_{3} \mathrm{CN}(50: 50, \mathrm{v} / \mathrm{v}) \\
(\%)\end{array}$ \\
\hline 0 & 0 & 100 \\
\hline 5 & 30 & 70 \\
\hline 15 & 80 & 20 \\
\hline 20 & 90 & 10 \\
\hline 25 & 95 & 5 \\
\hline 30 & 100 & 0 \\
\hline
\end{tabular}

\section{Results And Discussion}

\subsection{Dominant PAH compounds}

The chemical formula, structure, and retention times of each compound of PAHs are summarized in Table 2.

In the present study, certified reference material was used for verification of PAHs, and each PAHs was identified on the basis of retention time marked in the chromatograms and quantified by uv/vis detector responses of the samples with the corresponding peaks of authentic standard solution (Supelco : Lot 125H0792). Separation for individual NPTHL, ANCPL, PHEN, ANTHR, FLRTH, PYR, CHRY, BaP, DahA, BghiP and I123cdP in the standard solution was satisfactory by the HPLC system, while ACNPN, FLURN, BbF and BkF were not sharply separated with uv/vis detection (Fig. 2).

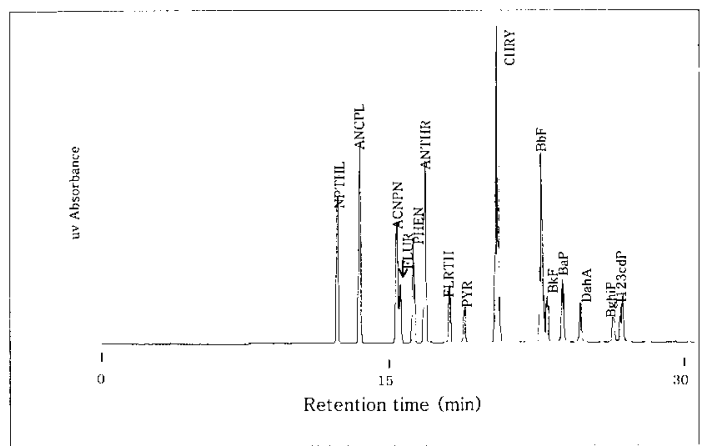

Fig. 2. Chromatogram of PAH standard solution by HPLC with uv/vis detection. BaA can't eluted at $254 \mathrm{~nm}$.

The concentrations of PAHs in mussels from 
Table 2. The chemical formula, structures and retention times(Rt) of PAHs analyzed in the study

mw : molecular weight

\begin{tabular}{|c|c|c|c|c|c|}
\hline No. & $\begin{array}{l}\text { COMPOUND } \\
\text { (ABBREV) }\end{array}$ & $\begin{array}{l}\text { ALTERNATIVE } \\
\text { NAME }\end{array}$ & $\begin{array}{l}\text { FORMULAR } \\
\text { (MW) }\end{array}$ & STRUCTURE & $\mathrm{Rt}(\min )^{*}$ \\
\hline 1 & Naphthalene(NPTHL) & & $\mathrm{C}_{10} \mathrm{H}_{8}(128)$ & & 12.16 \\
\hline 2 & Acenaphthylene(ANCPL) & & $\mathrm{C}_{12} \mathrm{H}_{8}(152)$ & & 13.28 \\
\hline 3 & Acenaphthene(ACNPN) & & $\mathrm{C}_{12} \mathrm{H}_{10}(154)$ & & 15.15 \\
\hline 4 & Fluorene(FLURN) & & $\mathrm{C}_{12} \mathrm{H}_{10}(166)$ & & 15.38 \\
\hline 5 & Phenanthrene(PHEN) & & $\mathrm{C}_{14} \mathrm{H}_{10}(178)$ & & 16.00 \\
\hline 6 & Anthracene(ANTHR) & & $\mathrm{C}_{14} \mathrm{H}_{10}(178)$ & & 16.55 \\
\hline 7 & Fluoranthene(FLRTH) & & $\mathrm{C}_{16} \mathrm{H}_{10}(202)$ & & 17.80 \\
\hline 8 & Pyrene(PYR) & & $\mathrm{C}_{16} \mathrm{H}_{10}(202)$ & & 18.55 \\
\hline 9 & Chrysene(CHRY) & & $\mathrm{C}_{18} \mathrm{H}_{12}(228)$ & & 20.13 \\
\hline 10 & Benzo(b)fluoranthene(BbF) & 3,4 Benzfluoranthene & $\mathrm{C}_{20} \mathrm{H}_{12}(252)$ & & 22.40 \\
\hline 11 & Benzo(k)fluoranthene(BkF) & 11,12 Benzfluoranthene & $\mathrm{C}_{20} \mathrm{H}_{12}(252)$ & & 22.73 \\
\hline 12 & Benzo(a)pyrene(BaP) & 3,4 Benzopyrene & $\mathrm{C}_{20} \mathrm{H}_{12}(252)$ & & 23.45 \\
\hline 13 & $\begin{array}{l}\text { Dibenz(a.h)anthracene } \\
\text { (DahA) }\end{array}$ & $\begin{array}{c}1,2,5,6 \\
\text { Dibenzanthracene }\end{array}$ & $\mathrm{C}_{22} \mathrm{H}_{14}(278)$ & & 24.33 \\
\hline 14 & $\begin{array}{l}\text { Benzo(g.h.i)peryline } \\
\text { (BghiP) }\end{array}$ & 1,12 benzperylene & $\mathrm{C}_{22} \mathrm{H}_{12}(276)$ & & 26.06 \\
\hline 15 & Indeno(1.2.3-cd)pyrene $\left(\mathrm{I}_{123} \mathrm{~cd} P\right)$ & o -Phenylenepyrene & $\mathrm{C}_{22} \mathrm{H}_{12}(276)$ & & 26.40 \\
\hline
\end{tabular}

The Retention times of PAHs analyzed were drawn from uv/vis detection.

six sites are presented in Table 3 . And the representative chromatograms of PAHs of mussels analyzed by uv/vis detection at site 6 are presented in Fig. 3. The highest PAH content observed was ANCPL(5,900 ppb) in mussels at site 2 near the nuclear power plant. The second most highest PAH compound was NPTHL(81 ppb), and DahA, BbF, BaP were the next dominant PAH group in mussels in the study area. I123cdP, however, was not detected in any mussel ay all sites.

Total PAHs ranged from ranged from 119.8 to $6,351.3$ (mean $1,923 \pm 1,069 \mathrm{ppb}$ ) in mussels in the study area. The total PAHs in mussels reported in Chinhae bay, Korea ${ }^{5)}$, ranged from 498 to 2,060 ppb wet wt(mean $760 \mathrm{ppb}$ ). Compared the present study with Lee's result in Chinhae bay, the PAH content in mussels from Kori and Chinhae bay showed generally similar. The levels of PAHs in marine ecosystem have been well documented in other countries, but not much data are available in Korea.

\subsection{Comparison with data of foreign counties}

The total PAH content in mussel in the Gulf of

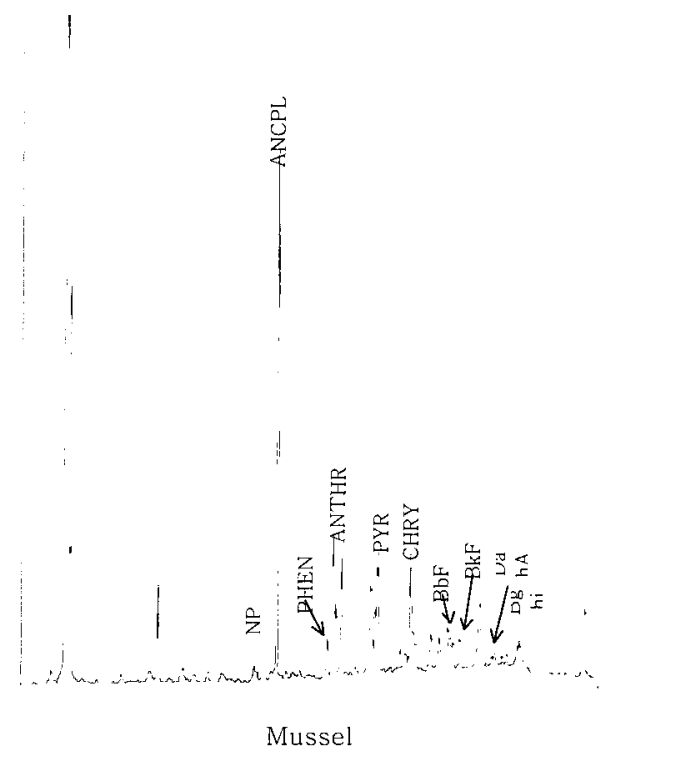

Fig. 3. Chromatogram of PAHs in mussel with uv/vis detection at site 6 .

Naples from Italian Central Mediterranean coasts ${ }^{2)}$ varied from 2 to $60 \mathrm{ppb}$ (Table 3). Most individual 
Table 3. The concentration of PAHs in mussels $(\mu \mathrm{g} / \mathrm{kg}$ wet wt) from the intertidal zone of Kori.

\begin{tabular}{l|c|c|c|c|c|c|c|c}
\hline & Site 1 & Site & Site 3 & Site 4 & Site 5 & Site 6 & ${\text { Mean } \pm \text { SE }^{*}}^{{ }^{a} \text { Italy }}$ \\
\hline NPTHL & 22.5 & 85.5 & 334 & 16.5 & 25 & 2.5 & $81 \pm 51$ & ND \\
\hline ANCPL & 42 & 5,900 & 3,260 & 290 & 26.5 & 565 & $1,680 \pm 981$ & 60 \\
\hline ACNPN & ND & ND & 129 & ND & ND & ND & 126 & 35 \\
\hline FLURN & ND & ND & 117 & ND & ND & ND & 65 & 5 \\
\hline PHEN & 8 & 5.5 & 1.5 & 0.02 & 1.5 & 3 & $3.3 \pm 1.3$ & 4 \\
\hline ANTHR & ND & 31.5 & 17.5 & 3.5 & 10.8 & 11.5 & $15 \pm 4.7$ & 5 \\
\hline FLRTH & ND & 10.5 & 16.5 & 2 & 3 & 4.5 & $7.3 \pm 2.7$ & 21 \\
\hline PYR & 17.5 & 10.3 & 34.5 & 13 & 17 & 24 & $19 \pm 3.5$ & 24 \\
\hline CHRY & 1.5 & 2 & 1.5 & ND & 2.5 & 8.5 & $3.2 \pm 1.3$ & 13 \\
\hline BbF & 11.5 & 26 & 27 & 6 & 18.5 & 10 & $16.5 \pm 3.5$ & 46 \\
\hline BkF & 15.5 & 10.5 & 2.5 & 10.5 & 1.5 & 6 & $7.8 \pm 2.1$ & 4 \\
\hline BaP & 3 & 64 & 6 & 3 & 2.5 & ND & $15.7 \pm 12$ & 5 \\
\hline DahA & 5.5 & 77.5 & 5.5 & ND & 11 & 1.6 & $20.2 \pm 14.3$ & 20 \\
\hline BghiP & ND & 128 & ND & 3.1 & ND & 4.1 & $72 \pm 41$ & 22 \\
\hline I 23 cd & ND & ND & ND & ND & ND & ND & & \\
\hline Total & 127 & $6,351.3$ & $3,952.5$ & 347.6 & 119.8 & 640.7 & $1,923 \pm 1,069$ & \\
\hline
\end{tabular}

'SE : Standard Error, ND : Not detected

${ }^{a}$ Italy : Cocchieri et al.(1990) ${ }^{2)}$

PAH contents in the Gulf of Naples were very similar to those in mussels from Kori, Korea, except NPTHL and ANCPL(see Table 3). NPTHL was not reported in mussels in the Gulf of Naples, whereas $1123 \mathrm{cdP}$ was not detected in mussels from Kori. ANCPL in mussels from Kori was much higher than that in Naples.

Among the PAH contents analyzed in Yaquina $\mathrm{Bay}^{8)}$, the concentration of PHEN, FLRTH and PYR were much higher than those in Kori, Korea. While BbF and BghiP in Kori, Korea showed a little higher concentration than those in Yaquina Bay.

In summary, it seems that PAH contents in mussels in Kori, Korea showed similar as somewhat polluted areas of other countries, however, we can not ascertain that the PAH concentration in organisms in Kori might attain to the serious level in the present time. More data on PAH concentration in marine environment in the East Sea area need to be accumulated in near future.

\subsection{The sources of PAHs}

Pyrogenic or combustion-derived PAH assemblages are relatively enriched in three to five-ring
PAH compounds( $3 \sim 5$ ring), whereas uncombusted fossil fuels are highly enriched in the two to three-ring PAHs $(2 \sim 3 \text { ring })^{1)}$. As shown in table 3 , most $\mathrm{PAH}$ of $2 \sim 3$ ring were much dominant than those of $3 \sim 5$ ring in mussels in the study area, i.e. the high molecular PAHs were less dominant(Fig. 4).

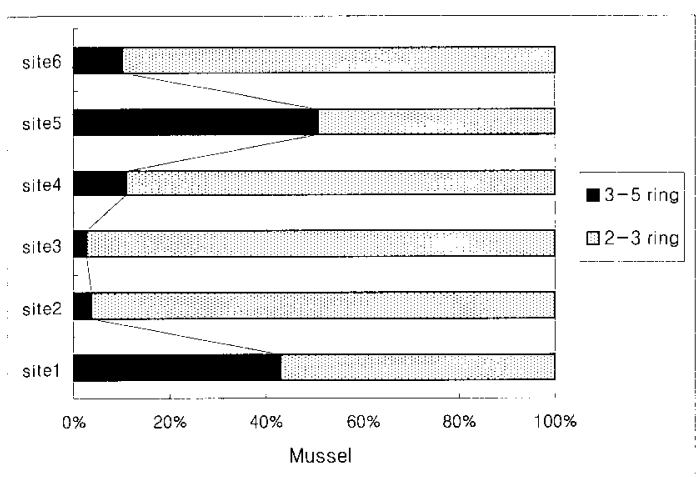

Fig. 4. The ratio of $2 \sim 3$ ring/ $3 \sim 5$ ring of PAHs in mussels in the study area.

Phenanthrenes compound may be of petrogenic, or diagenetic in origin, naphthalene compounds are characteristic of fresh crude oil, therefore, the 
ratio of naphthalene to phenanthrene is particularly diagnostic for inputs of fresh petroleum. The N/P (Naphthalene/Phenanthrene) ratio is much greater than 1.0 for most petroleums and decreases up to below 0.2 in clean sediments ${ }^{14)}$. These ratios are useful in defining the hydrocarbon composition of the marine organisms and sediments, and in distinguishing the relative importance of petroleumderived(petrogenic) hydrocarbons versus biologically derived(biogenic) or combustion-derived (pyrogenic) hydrocarbons.

In this study, the N/P ratio ranged from 2.8 to 825 (mean 147) in mussels except at site 6. I suggest that the PAHs in mussels and in the study area is mostly fresh petroleum-derived. Also the relative abundance of two to three-ring PAHs in mussels ranged from $58 \%$ to $90 \%$ of the total(Fig. 4). This confirms the idea that the major source of PAHs in the study area is not combustion-derived. Rather, the major source of PAHs in the study area could be domestic and industrial effluents containing uncombusted fossil fuels, and/or engine or fuel oil spilled from the vessels navigating.

I suggest that seasonal variations of PAH concentrations in mussels, sediment, and seawater as well as other marine organisms in the study area need to be investigated in the future in order to support the above conclusion.

\section{Conclusions}

NPTHL and ANCPL were dominant PAH compounds in mussels living in the intertidal zone of Kori, Korea, and DahA, BbF, BaP were the next dominant PAH group in mussels in the study area.

It seems that PAH contents in mussels in Kori, Korea, showed similar as somewhat polluted areas of other countries, however, I can not ascertain that the PAH concentration in organisms in Kori might attain to a serious level in the present time. More data on PAH concentration in marine environment in the East Sea area need to be accumulated in near future.

According to $\mathrm{N} / \mathrm{P}$ (Naphthalene/Phenanthrene) ratio in mussels in the study area, and the ratio of $2 \sim 3$ ring to $3 \sim 5$ ring $\mathrm{PAH}$ in mussels, we expect that the major sources of PAHs in this study area is rather fresh petroleum-derived. Therefore domestic and industrial effluents containing un- combusted petroleum and fresh fossil fuels from ships navigating the study area could directly affect the PAH contamination in the study area.

\section{Acknowledgement}

This study was carried out upon supporting by Korea Research Foundation(KRF-97-022-H0002.)

\section{References}

[1] Boehm, P. D. and Farrington, J. W. 1984. Aspects of the polycyclic aromatic hydrocarbon geochemistry of recent sedimints in the Georges Bank region. Environ. Sci. Technol., 18, 840 845 .

[2] Cocchieri, R. A., A. Arnese, A. M. Minicucci. 1990. Polycyclic aromatic hydrocarbons in marine organisms from Italian Central Mediterranean Coasts. Marine Pollution Bull., 21 (1), $15 \sim 18$.

[3] Delanne, R. D., Patrick, W. H., Casselman, JR and M. E. 1981. Effect of sediment $\mathrm{pH}$ and redox conditions on degradation of Benzo (a)pyrene, Marine Pollution Bull., 12(7). 251 $\sim 253$.

[4] Law, R. J and J. A. Whinnett. 1992. Polycyclic aromatic hydrocarbons in muscle tissue of harbour porpoises(Phocoena phocoena) from UK Waters. Marine Pollution Bull., 24(11), $550 \sim 553$.

[5] Lee, K. S. 1997. The High performance liquid chromatography(hplc) analysis of polycyclic aromatic hydrocarbons(pahs) in mussels and oysters from the intertidal and subtidal zones of Chinhae bay, Korea. Master's thesis, Korea Maritime University.

[6] Means, J. C., S. G. Wood, J. H. Hassett, and W. L. Banwart, 1980. Sorption of polynuclear aromatic hydrocarbons by sediments and soils. Envoron. Sci. Technol., 14, 1524 1528.

[7] Menzie C. A., B. B. Potocki and J. Santodonato, 1992. Esposure to carcinogenic pahs in the environment. Envoron. Sci. Technol., 26(7), 1278 1284.

[8] Mix, M. C. and R. L. Schaffer. 1983. Concentration of unsubstituted polynuclear aromatic hydrocarbons in bay mussels(mytilus 
edulis) from Oregon, USA. Marine Environmental Research. 9, 193 209

[9] Natush, D. F. S., B. A. Tomkins. 1978. Isolation of polycyclic organic compounds by solvent extraction with dimethylsulfoxide. Anal. Chem. 50, 1429 1434.

[10] Neff, J. M. 1985. Polycyclic aromatic hydrocarbons, in Fundamentals of Aquatic Toxicology, Rand, G. M. and Pterocelli, S. M. Eds., Hemisphere, New York.

[11] Rainio, K., R. R. Linko, and L. Ruotsila. 1986. Polycyclic aromatic hydrocarbons in mussel and fish from the Finnish Archipelago Sea. Bull. Environ. Contam. Texicol., 37, 337 343.

[12] Smith, J. D., J. Bagg, and B. M. Bycroft.
1984.Polycyclic aromatic hydrocarbons in the clam Tridacna Maxima from the Great Barrier Reef, Australia. Environ. Sci. Technol., 18, $353 \sim 358$.

[13] Smith, J. D., J. Bagg, and Y. O. Sin. 1987. Aromatic hydrocarbons in seawater, sediments and clams from Green Island. Great Barrier Reef, Australia. Mar. Freshw. Res., $38: 501 \sim 510$.

[14] Steinhauer, M. S. and P. D. Boehm. 1992. The Composition and distribution of saturated and aromatic hydrocarbons in nearshore sediments, river sediments, and coastal peat of the alaskan beaufort sea: implications for detection anthropogenic hydrocarbon inputs. Marine Environ. Res., 33. 223 253. 